\author{
Yersa Novellina Putri \\ Jurusan Ilmu Administrasi Publik, Fakultas Ilmu Sosial, Universitas Negeri Padang \\ yersapitopang@gmail.com \\ Dasman Lanin \\ Jurusan Ilmu Administrasi Publik, Fakultas Ilmu Sosial, Universitas Negeri Padang \\ dasmanlanin@gmail.com
}

\begin{abstract}
This study aimed to determine the contribution of public service innovation on customer satisfaction in issuing passports at the Office of Immigration Class I Padang. The background of this research was that there were many people complained about the queue for passport request. This study was conducted through a quantitative approach. The population in this study was all Indonesian Citizens (WNI) who had received passport request services from the Office of Immigration Class I Padang from January to June 2018 totaling 16.311. The sample in this study consisted of 390 respondents determined with Slovin Formula and through a proportionate stratified random sampling technique. Data in this study were collected through questionnaires with Likert Scale measurement. The data were analyzed using multiple linear regression tests. The partial test results showed that the novelty dimension (X1), the productive dimension (X2), the impact dimension (X3), and the sustainability dimension (X4) had a significant contribution on customer satisfaction with a significance value of 0,000. While simultaneously public service innovations (consisted of novelty, productive, impact, and sustainability) had a significant contribution on customer satisfaction in issuing passports at the Office of Immigration Class I Padang.
\end{abstract}

Keywords: Public service innovation, customer satisfaction, passport

How to Cite: Yersa Novellina Putri and Dasman Lanin. 2018. Kontribusi Inovasi Pelayanan Publik terhadap Kepuasan Pelanggan dalam Penerbitan Paspor di Kantor Imigrasi Kelas I Padang. 2(2) : pp. 159-171. DOI: https://doi.org/10.24036/jess/vol2-iss2

\title{
Pendahuluan
}

Salah satu tugas utama Negara adalah memberikan pelayanan kepada masyarakat (pelanggan) baik dalam bentuk jasa maupun fasilitas. Tingkat kesadaran masyarakat yang semakin tinggi terhadap penyelenggaraan pelayanan publik menuntut para penyelenggara pemerintahan sebagai pemberi pelayanan untuk dapat memberikan pelayanan yang terbaik di sektor publik. Sektor publik merupakan sektor yang bergerak dalam bidang pelayanan jasa, salah satunya 
Kantor Imigrasi Kelas I Padang yang merupakan Kantor Wilayah Kemenkumham yang berada di provinsi.

Kantor imigrasi merupakan Unit Pelayanan Teknis yang menjalankan fungsi Direktorat Jendral Imigrasi. Jenis pelayanan terbanyak di Kantor Imigrasi adalah pelayanan penerbitan Surat Perjalanan Republik Indonesia (SPRI)/ Paspor. Pada tahun 2016 penerbitan paspor RI di Kantor Imigrasi Kelas I Padang sebanyak 31.591 (tiga puluh satu ribu lima ratus sembilan puluh satu) dokumen. Sedangkan untuk tahun 2017 sebanyak 30.103 (tiga puluh ribu seratus tiga) dokumen. Tingginya jumlah permohonan Paspor ini memberikan beban kerja yang lebih bagi Kantor Imigrasi Kelas I Padang untuk memberikan pelayanan pembuatan paspor. Untuk mengatasi beban kerja yang tinggi karena banyaknya jumlah pemohon paspor di Kantor Imigrasi Kelas I Padang maka dilakukanlah inovasi pelayanan untuk meningkatkan kinerja dan kualitas pelayanan agar tercapai kepuasan masyarakat.

Inovasi adalah alat untuk mencapai tujuan, sebuah apresiasi terhadap pentingnya keragaman inovasi dan bagaimana mencapainya, harus menjadi bagian dari pengetahuan, keterampilan, dan perilaku dari setiap pekerja pemerintah. (Dhewanto, dkk. 2014). Menurut pemikiran LAN (dalam Deddy Mulyadi et al. (2016), pentingnya dilakukan inovasi dalam administrasi publik karena banyaknya permasalahan kinerja pelayanan organisasi publik; kondisi birokrasi pemerintahan berada dalam nuansa zona nyaman birokrasi; urusan dan masalah dalam birokrasi pemerintah ataupun organisasi publik sangat dinamis untuk ditangani segera; tuntutan globalisasi; serta perkembangan dan kemanjuan teknologi informasi.

Kantor Imigrasi Kelas 1 Padang telah melakukan beberapa terobosan baru terkait dengan pemberian jasa pelayanan kepada masyarakat melalui berbagai inovasi. Salah satu bentuk inovasi terbarunya dalam pelayanan pembuatan paspor yaitu melalui Aplikasi Antrian Paspor secara online yang menggantikan cara walk in atau manual dalam mendapatkan nomor antrian yang didasarkan oleh Surat Edaran Direktur Jenderal Imigrasi Nomor IMI-UM.01.01-4166 tanggal 16 Oktober 2017 tentang Implementasi Aplikasi Pendaftaran Antrian Permohonan Paspor Secara Online di seluruh Indonesia. Sebelumnya untuk mendapatkan nomor antrian permohonan paspor menggunakan antrian berbasis kuota jumlah (didasarkan jumlah sesuai kapasitas produksi perbooth/hari), selanjutnya diubah menjadi antrian berbasis waktu (berdasarkan batas waktu tertentu).

Berdasarkan hasil wawancara penulis dengan Kepala Sub Seksi Informasi pada tanggal 8 Maret 2018 tujuan adanya Aplikasi Antrian Paspor online ini adalah untuk memudahkan masyarakat dalam memperoleh nomor antrian dalam pelayanan paspor. Dalam penerapannya terindikasi hambatan/kendala dalam penerapan inovasi antrian paspor online ini seperti tidak semua masyarakat memiliki ponsel android dan tidak semua masyarakat mengerti cara mengunduhnya ataupun menggunakannya serta terjadinya SPAM. Adanya SPAM atau pemohon tidak hadir setiap harinya, kemungkinan penyebabnya bisa kdisebabkan: pemohon yang bersangkutan berhalangan hadir, mendaftar lebih dari 1 kali, salah memilih waktu/tempat dan masyarakat yang coba-coba. Selain itu juga terjadi full booking pada aplikasi antrian paspor. Hal ini terjadi karena kurangnya kuota nomor antrian tersebut. 
Selain implementasi layanan antrian paspor online, inovasi lain yang dilakukan Kantor Imigrasi Kelas I Padang yaitu pelayanan pembayaran Penerimaan Negara Bukan Pajak (PNBP) keimigrasian melalui SIMPONI didasarkan pada Surat Edaran Direktrur Jenderal Imigrasi Nomor IMI.3.GR.01.10-1.996 tanggal 25 September 2017 tentang Perubahan Sistem Permohonan Izin Tinggal Keimigrasian (Izin Tinggal Kunjungan, Izin Tinggal Terbatas, dan Izin Tinggal Tetap) secara online dan Pembayaran PNBP melalui SIMPONI di seluruh kantor Imigrasi. Selain itu, juga diterapkan implementasi pelayanan jasa pengiriman paspor RI (passport delivery service) melalui PT.POS Indonesia (Persero) Padang dengan didasarkan oleh Surat Edaran Direktur Jenderal Imigrasi Nomor IMI-UM.01.01-3141, tanggal 05 September 2017 tentang Layanan Pengiriman Paspor Melalui Jasa Pos. Hal ini dimaksudkan untuk memberikan kemudahan, kecepatan dan keamanan pelayanan kepada masyarakat dalam pengiriman paspor yang bekerjasama dengan PIHAK KEDUA melalui pelayanan pengiriman paspor.

Berdasarkan uraian di atas maka peneliti telah melaksanakan penelitian di Kantor Imigrasi Kelas I Padang mengenai kontribusi inovasi pelayanan publik terhadap kepuasan pelanggan dalam penerbitan paspor di Kantor Imigrasi Kelas I Padang dengan rumusan masalah penelitian sebagai berikut:

1) Apakah terdapat kontribusi inovasi pelayanan publik terhadap kepuasan pelanggan dalam penerbitan paspor di Kantor Imigrasi Kelas I Padang?

2) Apakah ada kontribusi dimensi kebaruan (novelty) terhadap kepuasan pelanggan dalam penerbitan paspor di Kantor Imigrasi Kelas I Padang ?

3) Apakah ada kontribusi dimensi produktif (productive) terhadap kepuasan pelanggan dalam penerbitan paspor di Kantor Imigrasi Kelas I Padang ?

4) Apakah ada kontribusi dimensi berdampak (impact) terhadap kepuasan pelanggan dalam penerbitan paspor di Kantor Imigrasi Kelas I Padang ?

5) Apakah ada kontribusi dimensi berkelanjutan (sustainability) terhadap kepuasan pelanggan dalam penerbitan paspor di Kantor Imigrasi Kelas I Padang ?

\section{Tinjauan Kepustakaan}

\section{Inovasi Pelayanan Publik}

Peraturan Menteri Pendayagunaan Aparatur Negara dan Reformasi Birokrasi Republik Indonesia Nomor 30 Tahun 2014 tentang Pedoman Inovasi Pelayanan Publik, menjelaskan bahwa Inovasi Pelayanan Publik adalah terobosan jenis pelayanan baik yang merupakan gagasan/ide kreatif orisinal dan/atau adaptasi/modifikasi yang memberikan manfaat bagi masyarakat, baik secara langsung maupun tidak langsung. Dengan kata lain, inovasi pelayanan publik sendiri tidak mengharuskan suatu penemuan baru, tetapi dapat merupakan suatu pendekatan baru yang bersifat kontekstual dalam arti inovasi tidak terbatas dari tidak ada kemudian muncul gagasan dan praktik inovasi, tetapi dapat berupa inovasi hasil dari perluasan maupun peningkatan kualitas pada inovasi yang ada. 
Dalam konteks pelayanan publik, inovasi bisa diartikan sebagai pembaharuan/kreativitas/ciptaan baru dalam pelayanan publik untuk meningkatkan kualitas layanan (Fitriana, 2014). Menurut Gumilar (2016) inovasi pelayanan publik adalah penciptaan maupun pemanfaatan ide, praktik, produk, jasa, metode, proses atau prosedur baru dalam pelayanan publik secara sengaja agar memberikan manfaat secara signifikan bagi penyelenggara pelayanan dan pengguna layanan. Dari beberapa pengertian tersebut dapat dipahami bahwa inovasi pelayanan publik merupakan suatu ide/gagasan, produk, cara baru dalam teknologi pelayanan ataupun perbaikan atau perluasan dari inovasi yang sudah ada sebelumnya yang memberikan manfaaat bagi pelayanan publik.

Berdasarkan panduan pengukuran indeks persepsi inovasi pelayanan publik yang diterbitkan oleh Pusat Inovasi Pelayanan Publik, Kedeputian Inovasi Administrasi Negara, Lembaga Administrasi Negara (Suprihatini, 2017) ada empat dimensi untuk dijadikan indikator mengukur inovasi pelayanan publik yaitu:

1) Kebaruan (pendekatan baru); Kebaruan (pendekatan baru) adalah memperkenalkan gagasan yang unik, pendekatan yang baru dalam penyelesaian masalah, atau kebijakan dan desain pelaksanaan yang unik, atau modifikasi dari inovasi pelayanan publik yang telah ada dalam rangka penyelenggaraan pelayanan publik. Indikator untuk mengukur kebaruan dapat berupa perbaikan, sebagai berikut: 1) Perbaikan layanan: maksudnya ada perbaikan dalam pemberian pelayanan dari sebelumnya; 2) Keunikan layanan: maksudnya ada keunikan dalam pemberian pelayanan; 3) Layanan jenis baru: maksudnya ada pelayanan baru yang diberikan kepada masyarakat; 4) Petugas selalu ada: maksudnya petugas pelayanan publik selalu ada pada saat masyarakat membutuhkan layanan; 5) Informasi layanan: maksudnya informasi tentang layanan publik dapat diperoleh secara mudah, jelas, tepat dan dapat dipertanggungjawabkan; 6) Persyaratan layanan: maksudnya persyaratan yang diperlukan untuk mendapatkan pelayanan cukup sederhana; 7) Proses layanan: maksudnya proses pelayanan publik cukup mudah dan ringkas; dan 8) Teknologi informasi layanan: maksudnya pelayanan publik telah didukung teknologi informasi yang memadai.

2) Produktif; Produktif adalah program/kegiatan implementasi inovasi pelayanan publik yang mampu menghasilkan perbaikan pelayanan publik yang dapat dibuktikan. Indikator untuk mengukur produktifnya inovasi pelayanan publik dapat berupa perbaikan sebagai berikut: 1) Pemberian layanan: maksudnya petugas pelayanan publik memberikan pelayanan secara cepat, tepat dan benar; 2) Produk layanan: maksudnya produk layanan telah memenuhi kebutuhan; 3) Standar layanan: maksudnya pelayanan yang diberikan sesuai dengan standar yang telah ditetapkan; 4) Kualitas layanan: maksudnya pelayanan publik yang diberikan memiliki kualitas sesuai dengan yang diharapkan; dan 5) Transparansi layanan: maksudnya masyarakat dapat memantau secara online (telepon, SMS, fax, internet, media sosial, dll) terhadap proses pelayanan publik. 
3) Berdampak; Berdampak adalah memberikan manfaat terhadap peningkatan atau perubahan kondisi dan sebagai daya ungkit terhadap percepatan peningkatan kualitas pelayanan publik. Indikator untuk mengukur berdampaknya inovasi pelayanan publik dapat berupa hal-hal berikut: 1) Penyelesaian permasalahan: maksudnya cara baru dalam pemberian pelayanan dapat menyesuaikan permasalahan yang ada; 2) Kesesuaian layanan: maksudnya cara baru dalam pemberian pelayanan memenuhi kebutuhan sesuai harapan; 3) Ketersediaan layanan secara inklusif: maksudnya ketersediaan sarana dan prasarana layanan publik memenuhi semua kebutuhan kelompok masyarakat (umur, jenis kelamin, pendidikan, berkebutuhan khusus, kondisi ekonomi, dll); dan 4) Layanan terintegrasi: maksudnya adanya pelayanan publik yang terintegrasi dan/atau terpusat.

4) Berkelanjutan; Berkelanjutan maksudnya adalah memberikan jaminan bahwa inovasi pelayanan publik terus dipertahankan, diimplementasikan, dan dikembangkan dengan dukungan program dan anggaran, tugas dan fungsi organisasi, serta hukum dan perundang-undangan. Indikator untuk mengukur berkelanjutannya inovasi pelayanan publik dapat berupa hal-hal sebagai berikut: 1) Konsistensi pelayanan: maksudnya terdapat konsistensi/keajegan cara baru dalam pemberian pelayanan; 2) Peningkatan perbaikan layanan: maksudnya terdapat peningkatan perbaikan layanan secara terus menerus; 3) Pengaduan masyarakat: maksudnya pengaduan masyarakat di respon secara cepat; dan 4) Tanggapan terhadap aduan: maksudnya penyedia layanan memberikan penyesuaian aduan secara tepat.

\section{Kepuasan Masyarakat}

Lukman (dalam Pasolong, 2010) menyatakan bahwa kepuasan adalah tingkat persamaan seseorang setelah membandingkan kinerja (hasil) yang dirasakan dengan harapannya. Lanin dan Hermanto (2016) mengungkapkan kepuasan pelanggan atau masyarakat adalah tanggapan yang diungkapkan oleh sesorang yang dihasilkan dari perbandingan antara kinerja layanan yang dirasakan yang terjadi dalam waktu tertentu dan harapan sebelumnya. Disamping itu, Willkie (dalam Surjadi, 2009) menyatakan bahwa kepuasan pelanggan merupakan suatu tanggapan emosional pada evaluasi terhadap pengalaman konsumsi produk atau jasa. Sedangkan Engel (dalam Surjadi, 2009) mengartikan kepuasan pelanggan sebagai evaluasi purnabeli dimana alternatif yang dipilih sekurang-kurangnya sama atau melampaui harapan pelanggan, sedangkan ketidaksesuaian timbul apabila hasil (outcome) tidak memenuhi harapan. Dari serangkaian pengertian tentang kepuasan pelanggan di atas dapat diketahui bahwa kepuasan pelanggan (masyarakat) adalah penilaian atau tanggapan yang diberikan pelanggan terhadap produk atau jasa yang telah mereka terima apakah memenuhi harapan atau tidak memenuhi harapan pelanggan.

Dalam melakukan pengukuran terhadap tingkat kepuasan pelanggan pada pelayanan publik, pemerintah telah menetapkan sebuah indeks pengukuran yang disebut dengan Indeks Kepuasan Masyarakat (IKM). Penggunaan IKM untuk 
mengukur tingkat kepuasan masyarakat terhadap pelayanan publik diatur dalam Permenpan Nomor 16 tahun 2014 tentang Pedoman Survei Kepuasan Masyarakat terhadap Penyelenggaraan Pelayanan Publik. Dalam melakukan survey kepuasan pelanggan, pemerintah telah mengatur indikator-indikator yang digunakan untuk mengukur tingkat kepuasaan masyarakat terhadap pelayanan publik. Terdapat 9 (Sembilan) ruang lingkup survey kepuasan yang digunakan yaitu:

1) Persyaratan, adalah syarat-syarat yang harus dipenuhi dalam pengurusan suatu jenis pelayanan, baik pelayanan teknis maupun pelayanan administratif.

2) Prosedur, adalah tata cara pelayanan yang dilakukan bagi pemberi dan penerima pelayanan termasuk pemberi dan penerima pengaduan.

3) Waktu pelayanan, adalah jangka waktu yang diperlukan untuk menyelesaikan seluruh proses pelayanan dari setiap jenis pelayanan.

4) Biaya/tarif, adalah ongkos yang dikenakan kepada penerima layanan dalam mengurus dan/atau memperoleh pelayanan penyelenggara yang besarnya ditetapkan berdasarkan kesepakatan antara penyelenggaraan dan masyarakat.

5) Produk spesifikasi jenis pelayanan, adalah hasil pelayanan yang diberikan dan diterima sesuai dengan ketentuan yang telah ditetapkan.

6) Kompetensi pelaksana, adalah kemampuan yang harus dimiliki oleh pelaksana meliputi pengetahuan, keahlian, keterampilan, dan pengalaman.

7) Perilaku pelaksana, adalah sikap petugas dalam memberikan pelayanan.

8) Maklumat pelayanan, adalah pernyataan kesanggupan dan kewajiban penyelenggara untuk melaksanakan pelayanan sesuai dengan standar pelayanan.

9) Penanganan pengaduan, saran, dan masukan, adalah tata cara pelaksanaan penanganan pengaduan dan tindak lanjut.

\section{Inovasi Pelayanan Publik dan Pengaruhnya Terhadap Kepuasan Pelanggan}

Ratminto dan Atik Septi Winarsih (dalam Indiahono, 2009) mengemukakan bahwa tujuan dari suatu pelayanan publik pada umumnya adalah dapat memuaskan masyarakat tanpa memandang apapun. Dalam sektor publik inovasi sangat diperlukan dalam pengembangan suatu pelayanan publik. Inovasi hadir sebagai sebuah produk yang baru dan sifatnya menggantikan cara yang lama (Mirnasari, 2013). Menurut Wahyudi (2016) inovasi pelayanan publik bisa diartikan sebagai pembaruan dalam penyelenggaraan pelayanan publik yang bisa dilakukan dari aspek proses maupun produk dan memberikan manfaat bagi masyarakat pengguna layanan. Mirnasari (2013) mengartikan inovasi di dalam pelayanan publik sebagai prestasi dalam meraih, meningkatkan dan memperbaiki efektivitas, efisiensi dan akuntabilitas pelayanan publik yang dihasilkan oleh inisiatif pendekatan, metodologi dan atau alat baru dalam pelayanan masyarakat.

Secara khusus inovasi di dalam lembaga publik bisa didefenisikan sebagai penerapan (upaya membawa) ide-ide baru dalam implementasi, dicirikan oleh adanya perubahan langkah yang cukup besar, berlangsung cukup lama dan berskala cukup umum sehingga dalam proses implementasinya berdampak cukup besar terhadap perubahan organisasi dan tata hubungan organisasi. Selanjutnya Kasmir (dalam Pasolong, 2010) menyatakan bahwa inovasi pelayanan yang baik 
adalah kemampuan seseorang dalam memberikan pelayanan yang dapat memberikan kepuasan kepada pelanggan dengan standar yang ditentukan.

Berdasarkan beberapa pendapat tersebut dapat dipahami bahwa inovasi pelayanan publik merupakan suatu pembaruan ataupun cara baru dalam penyelenggaraan pelayanan publik yang dibutuhkan bagi pengembangan pelayanan publik yang memberikan manfaat kepada pengguna layanan sehingga kepuasan pelanggan bisa didapatkan. Inovasi pelayanan merupakan langkah untuk meningkatkan kepuasan pelanggan terhadap pelayanan yang telah diterima. Inovasi memberikan jalan tengah untuk mempermudah masyarakat (pelanggan) dalam mengakses pelayanan yang diberikan oleh lembaga pemerintah. Adanya inovasi pelayanan publik diharapkan akan memberikan peningkatan kepuasan pelanggan atas pelayanan yang diberikan instansi pemerintah.

\section{Paspor}

Menurut Undang-Undang Republik Indonesia nomor 6 tahun 2011 tentang keimigrasian, paspor adalah dokumen yang dikeluarkan oleh Pemerintah Republik Indonesia kepada warga Negara Indonesia untuk melakukan perjalanan antar Negara yang berlaku selama jangka waktu tertentu. Di dalam Undang-Undang Republik Indonesia nomor 6 tahun 2011 tentang keimigrasian jenis-jenis paspor ada tiga macam yaitu (a) paspor diplomatik, (b) paspor dinas, dan (c) paspor biasa, dengan perincian sebagai berikut:

a. Paspor Diplomatik, diterbitkan bagi Warga Negara Indonesia yang akan melakukan perjalanan keluar Wilayah Indonesia dalam rangka penempatan atau perjalanan tugas yang bersifat diplomatik. Paspor diplomatik diterbitkan oleh Menteri Luar Negeri.

b. Paspor Dinas, diterbitkan bagi Warga Negara Indonesia yang akan melakukan perjalanan keluar Wilayah Indonesia dalam rangka penempatan atau perjalanan dinas yang tidak bersifat diplomatik. Paspor dinas diterbitkan oleh Menteri Luar Negeri.

c. Paspor biasa, diterbitkan untuk warga Negara Indonesia.Paspor biasa diterbitkan oleh Menteri atau Pejabat Imigrasi yang ditunjuk.

\section{Metode Penelitian}

Metode yang digunakan dalam penelitian ini adalah metode kuantitatif dengan bentuk penelitian asosiatif. Populasi dalam penelitian ini adalah seluruh Warga Negara Indonesia (WNI) yang telah mendapatkan pelayanan permohonan paspor dari Kantor Imigrasi Kelas I Padang pada Januari sampai Juni 2018 yang berjumlah 16.311. Sampel dalam penelitian ini berjumlah 390 responden yang ditentukan dengan menggunankan rumus Slovin dengan tingkat kesalahan 5\% sedangkan teknik pengambilan sampel menggunakan teknik proportional stratified random sampling.

Pengumpulan data dilakukan dengan menggunakan angket dengan pengukuran skala likert yang menggunakan 4 alternatif jawaban (sangat setuju, setuju, tidak setuju, sangat tidak setuju). Data dianalisis menggunakan teknik 
analisis uji regresi linier berganda yang diawali dengan uji asumsi klasik sebagaimana dipersyarakatkan dalam uji regresi.

\section{Hasil Penelitian dan Pembahasan}

\section{Temuan Penelitian}

Seperti yang telah dikemukakan dalam pendahuluan di atas, penelitian ini menjawab lima pertanyaan penelitian atau rumusan masalah. Rumusan masalah yang pertama yakninya apakah terdapat kontribusi inovasi pelayanan publik (yang mencakup keempat sub variabel kebaruan, produktif, berdampak, berkelanjutan) terhadap tingkat kepuasan pelanggan dalam pembutan paspor di Kantor Imigrasi Kelas I Padang? Untuk menjawab pertanyaan penelitian ini dapat dilihat hasil analisis datanya seperti yang ada pada Tabel 1 dan tebel 2 berikut ini:

Tabel 1. Hasil Kontribusi Variabel Inovasi Pelayanan Publik terhadap Variabel Kepuasan Pelanggan

\begin{tabular}{cccccc}
\multicolumn{8}{c}{ Model Summary $^{\mathbf{b}}$} \\
\hline Model & R & R Square & $\begin{array}{c}\text { Adjusted R } \\
\text { Square }\end{array}$ & $\begin{array}{c}\text { Std. Error of } \\
\text { the Estimate }\end{array}$ & Durbin-Watson \\
\hline 1 & $.677^{\text {a }}$ & .458 & .453 & .2637 & 1.780 \\
\hline
\end{tabular}

a. Predictors: (Constant), Rata-rata berkelanjutan, Rata-rata produktif, Rata-rata kebaruan, Rata-rata berdampak

b. Dependent Variable: Rata-rata kepuasan

Sumber : Olahan Data Peneliti 2018

Tabel 2. Hasil Uji Anova Inovasi Pelayanan Publik terhadap Kepuasan Pelanggan

ANOVA $^{b}$

\begin{tabular}{lccccc}
\hline Model & $\begin{array}{c}\text { Sum of } \\
\text { Squares }\end{array}$ & df & Mean Square & F & Sig. \\
\hline $1 \quad$ Regression & 22.653 & 4 & 5.663 & 81.471 & $.000^{\mathrm{a}}$ \\
$\quad$ Residual & 26.762 & 385 & .070 & & \\
$\quad$ Total & 49.416 & 389 & & & \\
\hline
\end{tabular}

a. Predictors: (Constant), rata-rata kebaruan, rata-rataproduktif, rata-rata berdampak, rata-rataberkelanjutan

b. Dependent Variable: Rata-Rata kepuasan

Sumber: Olahan Data Peneliti 2018

Berdasarkan tabel 1 di atas dapat dilihat nilai Adjusted $R$ Square dalam penelitian ini sebesar 0,453 yang artinya kontribusi variabel inovasi pelayanan publik terhadap kepuasan pelanggan di Kantor Imigrasi Kelas I Padang sebesar 45,3\%. Sedangkan untuk melihat interpretasi bahwa variabel inovasi pelayanan publik 
terhadap kepuasan pelanggan dalam penerbitan paspor di Kantor Imigrasi kelas I Padang dapat dikatakan signifikan. Hal ini terlihat pada Tabel 2, yang mana nilai signifikansinya adalah 0,000 , yang berarti bahwa nilai uji ini lebih kecil dari kategori signifikansi yang telah ditentukan yaitu 0,05. Artinya $\mathrm{H}_{0}$ ditolak dan $\mathrm{H}_{\mathrm{a}}$ diterima. Dengan demikian dapat disimpulkan bahwa terdapat kontribusi inovasi pelayanan publik terhadap kepuasan pelanggan dalam penerbitan paspor di Kantor Imigrasi Kelas I Padang sebesar 43,5\% dan kesimpulan ini dapat dipercaya sampai (sebesar) $100 \%$.

Selanjutnya rumusan masalah kedua, ketiga, keempat dan kelima yang ingin dijawab dalam penelitian ini adalah apakah ada pengaruh secara parsial/sendiri-sendiri dimensi kebaruan, dimensi produktif, dimensi berdampak dan dimensi berkelanjutan (sebagai sub variabel dari inovasi pelayanan publik) terhadap kepuasan pelanggan dalam penerbitan paspor di Kantor Imigrasi Kelas I Padang ? Secara ringkas hasil pengujian hasil uji regresi untuk rumusan masalah kedua, ketiga, keempat dan kelima dapat dilihat pada Tabel 3 berikut :

Tabel 3. Pengaruh Sub Variabel Kebaruan, Produktif, Berdampak dan Berkelanjutan terhadap Kepuasan Pelanggan di Kantor Imigrasi Kelas I Padang

\begin{tabular}{lcccc}
\hline \multicolumn{1}{c}{ Sub Variabel } & R & R Square & $\begin{array}{c}\text { Adjusted R } \\
\text { Square }\end{array}$ & Sig. \\
\hline Kebaruan & $.532^{\mathrm{a}}$ & .284 & .282 & $.000^{\mathrm{a}}$ \\
Produktif & $.508^{\mathrm{a}}$ & .258 & .256 & $.000^{\mathrm{a}}$ \\
Berdampak & $.570^{\mathrm{a}}$ & .325 & .323 & $.000^{\mathrm{a}}$ \\
Berkelanjutan & $.550^{\mathrm{a}}$ & .303 & .301 & $.000^{\mathrm{a}}$ \\
\hline
\end{tabular}

Sumber: Olahan Data Peneliti 2018

Tabel 3 di atas menunjukkan bahwa nilai Adjusted $R$ Square dimensi kebaruan sebesar 0,282 yang artinya kontribusi dimensi kebaruan terhadap kepuasan pelanggan adalah sebesar 28,2\%. Selanjutnya, berdasarkan hasil Uji Anova pada Tabel 3 di atas menunjukkan bahwa nilai signifikansi dimensi kebaruan adalah 0,000 yang artinya nilai uji ini lebih kecil dari kategori signifikansi yang telah ditentukan yaitunya 0,05 sehingga dapat disimpulkan bahwa $\mathrm{H}_{\mathrm{o}}$ ditolak dan $\mathrm{H}_{\mathrm{a}}$ diterima yang berarti terdapat kontribusi dimensi kebaruan terhadap kepuasan pelanggan dalam penerbitan paspor di Kantor Imigrasi Kelas I Padang.

Selanjutnya untuk dimensi produktif menunjukkan bahwa nilai Adjusted $R$ Square sebesar 0,256 yang artinya nilai kontribusi dimensi produktif terhadap kepuasan pelanggan adalah sebesar $25,6 \%$. Selain itu, berdasarkan hasil Uji Anova menunjukkan bahwa nilai signifikansi dimensi produktif adalah 0,000 yang artinya nilai uji ini lebih kecil dari kategori signifikansi yang telah ditentukan yaitunya 0,05 sehingga dapat disimpulkan bahwa $\mathrm{H}_{\mathrm{o}}$ ditolak dan $\mathrm{H}_{\mathrm{a}}$ diterima yang berarti terdapat kontribusi dimensi produktif terhadap kepuasan pelanggan dalam penerbitan paspor di Kantor Imigrasi Kelas I Padang. 
Untuk dimensi berdampak hasil uji regresi menunjukkan bahwa nilai Adjusted $R$ Square sebesar 0,323 yang artinya nilai kontribusi dimensi berdampak terhadap kepuasan pelanggan adalah sebesar 32,3\%. Selain itu, berdasarkan hasil Uji Anova menunjukkan bahwa nilai signifikansi dimensi berdampak 0,000 yang artinya nilai uji ini lebih kecil dari kategori signifikansi yang telah ditentukan yaitu 0,05 sehingga dapat disimpulkan bahwa $\mathrm{H}_{\mathrm{o}}$ ditolak dan $\mathrm{H}_{\mathrm{a}}$ diterima yang berarti terdapat kontribusi dimensi berdampak terhadap kepuasan pelanggan dalam penerbitan paspor di Kantor Imigrasi Kelas I Padang.

Selanjutnya untuk dimensi berkelanjutan, nilai Adjusted $R$ Square menunjukkan angka sebesar 0,301, yang artinya nilai kontribusi dimensi berkelanjutan terhadap kepuasan pelanggan adalah sebesar 30,1\%. Selain itu, berdasarkan hasil Uji Anova menunjukkan bahwa nilai signifikansi dimensi berkelanjutan 0,000 yang artinya nilai uji ini lebih kecil dari kategori signifikansi yang telah ditentukan yaitunya 0,05 sehingga dapat disimpulkan bahwa $\mathrm{H}_{\mathrm{o}}$ ditolak dan $\mathrm{H}_{\mathrm{a}}$ diterima yang berarti terdapat kontribusi dimensi berkelanjutan terhadap tingkat kepuasan pelanggan dalam penerbitan paspor di Kantor Imigrasi Kelas I Padang.

\section{Pembahasan}

Berdasarkan hasil uji dan analisis data penelitian yang telah dilakukan diperoleh hasil mengenai kontribusi inovasi pelayanan publik terhadap kepuasan pelanggan dalam penerbitan paspor di Kantor Imigrasi Kelas I Padang, baik secara uji parsial maupun uji simultan. Hasil penelitian ini menunjukkan bahwa dimensi kebaruan (X1), dimensi produktif (X2), dimensi berdampak (X3) dan dimensi berkelanjutan sebagai sub-sub variabel inovasi pelayanan publik yang merupakan variabel bebas, memiliki kontribusi terhadap kepuasan pelanggan (Y) yang merupakan variabel terikat. Dari hasil uji regresi berganda diperoleh nilai Adjusted $R$ Square sebesar 0,435 dengan persentase 43,5\%. Dengan demikian berarti bahwa kekuatan kontribusi variabel inovasi pelayanan publik terhadap kepuasan pelanggan dalam penerbitan paspor di Kantor Imigrasi Kelas I Padang adalah sebesar 43,5\%.

Dalam menentukan variabel bebas yang berkontribusi terhadap variabel terikat dapat dilihat dengan membandingkan nilai $\mathrm{R}$ antara satu variabel dengan variabel lainnya. Variabel yang memiliki nilai $\mathrm{R}$ paling besar berarti paling dominan kontribusinya terhadap variabel terikat. Perbandingannya dapat dilihat

pada sub variabel kebaruan $\left(\mathrm{X}_{1}\right)$ memiliki nilai $\mathrm{R} 0,532$, sub variabel produktif $\left(X_{2}\right)$ nilai $R$ nya sebesar 0,508 , sub variabel berdampak $(X 3)$ nilai $R$ nya sebesar 0,570 , dan sub variabel berkelanjutan $\left(\mathrm{X}_{4}\right)$ nilai $\mathrm{R}$ nya sebesar 0,550 . Jadi variabel yang paling dominan kontribusinya terhadap variabel terikat adalah variabel berdampak yaitu sebesar 57\%. Hasil temuan yang didapatkan menunjukkan bahwa sub variabel yang paling berkontribusi terhadap kepuasan pelanggan dalam penerbitan paspor adalah dimensi berdampak, karena berdampak merupakan sesuatu yang memberikan manfaat terhadap peningkatan atau perubahan kondisi dan sebagai daya ungkit terhadap percepatan peningkatan kualitas pelayanan publik sehingga akan dapat menciptakan kepuasan masyarakat. 
Hasil penelitian ini memperkuat pendapat Fitriana (2014) yang mengungkapkan inovasi di bidang pelayanan publik diartikan sebagai pembaharuan/kreativitas/ciptaan baru dalam pelayanan publik untuk meningkatkan kualitas layanan. Selain itu juga memperkuat pendapat Kasmir (dalam Pasolong, 2010), bahwa suatu produk dapat dikatakan berkualitas apabila memberikan kepuasan sepenuhnya kepada konsumen (masyarakat), yakninya sesuai dengan apa yang diharapkan konsumen (masyarakat) terhadap suatu produk (pelayanan). Artinya inovasi pelayanan publik yang berupa suatu cara baru dalam pemberian pelayanan mendatangkan manfaat untuk meningkatkan kualitas pelayanan dan pelayanan yang berkualitas apabila memberikan kepuasan kepada pelanggan yakni apa yang diharapkan pelanggan sesuai dengan kenyataan.

Selanjutnya berdasarkan hasil uji yang telah dilakukan secara parsial dapat dipahami bahwa dimensi berdampak sebagai subvariabel dari inovasi pelayanan publik memiliki kontribusi yang signifikan terhadap kepuasan pelanggan dalam penerbitan paspor di Kantor Imigrasi Kelas I Padang. Hasil penelitian ini sejalan dengan teori yang dikemukakan oleh Wahyudi (2016) bahwa inovasi pelayanan publik bisa diartikan sebagai pembaruan dalam penyelenggaraan pelayanan publik yang bisa dilakukan dari aspek proses maupun produk dan memberikan manfaat dan kepuasan bagi masyarakat pengguna layanan. Selain itu hasil penelitian ini juga memperkuat pendapat Gumilar (2016) yang mengemukakan bahwa penekanan dalam inovasi pelayanan publik selain sifat kebaruan, juga ditekankan keuntungan dan manfaatnya bagi kepuasan masyarakat sebagai pelanggan.

Selain itu, hasil penelitian ini juga memperkuat teori yang dikemukakan oleh Mulgan \& Albury (dalam Fitriana, 2014) bahwa inovasi pelayanan publik dikatakan berhasil jika merupakan hasil kreasi dan implementasi dari inovasi produk layanan, inovasi proses pelayanan, inovasi metode pelayanan, inovasi kebijakan, dan inovasi sistem. Inovasi produk atau layanan adalah perubahan bentuk dan desain produk atau layanan. Inovasi proses adalah pembaharuan kualitas yang berkelanjutan dan mengacu pada kombinasi perubahan organisasi, prosedur, dan kebijakan yang dibutuhkan untuk berinovasi. Sedangkan inovasi metode pelayanan adalah perubahan baru dalam hal berinteraksi dengan pengguna layanan atau cara baru dalam hal berinteraksi dengan pengguna layanan atau cara baru dalam memberikan pelayanan. Sementara inovasi dalam strategi atau kebijakan adalah perubahan visi, misi, tujuan dan strategi baru beserta alasannya yang berangkat dari realitas yang ada. Selanjutnya inovasi sistem adalah interaksi sistem yang mencakup cara baru atau yang diperbarui dalam berinteraksi dengan aktor-aktor lain atau dengan kata lain adanya perubahan dalam tata kelola pemerintahan.

\section{Penutup}

Berdasarkan hasil penelitian dan pembahasan yang telah dijelaskan di atas, maka dapat disimpulkan bahwa secara parsial dimensi kebaruan, produktif, berdampak, dan berkelanjutan memiliki kontribusi yang signifikan terhadap kepuasan pelanggan dalam penerbitan paspor di Kantor Imigrasi Kelas I Padang. Di sisi lain, secara simultan variabel inovasi pelayanan publik (yang terdiri kebaruan, 
produktif, berdampak, dan berkelanjutan) juga memiliki kontribusi yang signifikan terhadap kepuasan pelanggan dalam penerbitan paspor di Kantor Imigrasi Kelas I Padang.

Berdasarkan hasil penelitian dan kesimpulan yang telah dikemukakan sebelumnya maka melalui penelitian ini dapat dikemukakan beberapa saran antara lain:

1) Dari hasil penelitian menunjukkan bahwa pengaruh inovasi pelayanan publik terhadap tingkat kepuasan masyarakat dalam pembuatan paspor berpengaruh signifikan tehadap kepuasan pelanggan dalam penerbitan paspor dengan kontribusi sebesar 45,3\%. Pengaruh atau kontribusi dipandang cukup besar dan kuat serta cukup menentukan bagi kepuasan pelanggan. Dengan demikian disarankan kepada Kantor Imigrasi Kelas I Padang untuk lebih meningkatkan lagi inovasi pelayanan publik agar dapat lebih meningkatkan kepuasan pelanggan dalam pelayanan penerbitan paspor.

2) Peneliti masih menyadari bahwa hasil penelitian ini masih mengandung sesuatu yang belum diteliti dan kelemahan tertentu, maka dari itu diharapkan kepada peneliti selanjutnya untuk lebih menyempurnakan penelitian ini, dengan cara melibatkan lebih banyak variabel dan memperluas skop kajian agar hasilnya lebih representatif.

\section{DAFTAR KEPUSTAKAAN}

Dhewanto, Wawan dkk. (2014). Manajemen Inovasi: Peluang Sukses Menghadapi Perubahan. Yogyakarta: ANDI.

Fitriana, Diah Nur. (2014). Inovasi Pelayanan Publik BUMN (Studi Deskriptif tentang Inovasi Boarding Pass System dalam Meningkatkan Kualitas Pelayanan Kereta Api PT KAI di Stasiun Gubeng Surabaya). Jurnal Kebijakan dan Manajemen Publik. Volume 2, Nomor 1.

Gumilar, Panji Cahya. (2016). Inovasi Pelayanan Administrasi Terpadu Kecamatan Kota Sumenep, Kabupaten Sumenep. Jurnal Kebijakan dan Manajemen Publik. Volume 4, Nomor 3.

Indiahono, Dwiyanto. (2009). Perbandingan Administrasi Publik. Yogyakarta: Gava Media.

Lanin, Dasman dan Nailuredha Hermanto. (2016). The Analysis Of Foreigner Satisfaction And Service Quality Of Immigration Office Padang. Proceeding of International Conference On Ethics In Governance (ICONEG 2016) Volume 84.

Mirnasari, Rina Mei. (2013). Inovasi Pelayanan Publik UPTD Terminal PurabayaBungurasih. Jurnal Kebijakan dan Manajemen Publik. Volume 1 Nomor 1. 
Mulyadi, Deddy dkk. (2016). Administrasi Publik untuk Pelayanan Publik. Bandung: Alfabeta.

Pasolong, Harbani. (2010). Teori Administrasi Publik. Bandung: Alfabeta.

Peraturan Menteri Pendayagunaan Aparatur Negara dan Reformasi Birokrasi Republik Indonesia Nomor 30 Tahun (2014) tentang Pedoman Inovasi Pelayanan Publik

Peraturan Menteri Pendayagunaan Aparatur Negara dan Reformasi Birokrasi Nomor 16 tahun (2014) tentang Pedoman Survei Kepuasan Masyarakat terhadap Penyelenggaraan Pelayanan Publik

Suprihatini, Ani, dkk. (2017). Panduan Indeks Persepsi Inovasi Pelayanan Publik. Jakarta: Pusat Inovasi Pelayanan Publik, LAN RI.

Surjadi. (2009). Pengembangan Kinerja Pelayanan Publik. Bandung: Refika Aditama.

Undang-Undang Republik Indonesia nomor 6 tahun (2011) tentang Keimigrasian.

Wahyudi, Andi. (2016). Nilai Tambah dalam Inovasi Pelayanan Publik: Praktek di Unit Pelayanan Terpadu di Kota Pontianak dan Kabupaten Tanah Bumbu. Jurnal Bina Praja. Volume 8 (1). 